\title{
Korpuszalapú fordítástudomány, és ami mögötte van
}

\author{
Balaskó Mária
}

balasko.maria@sek.elte.hu

ELTE Savaria Egyetemi Központ

Angol Nyelv és Irodalom Tanszék

Kivonat: A korpusznyelvészetet és a leíró fordítástudományt egyaránt meghatározó szemléletmód értelmében a nyelvet úgy kell leírni, ahogyan az a természetes nyelvhasználatban létezik, azaz valódi, nem müvi nyelvi adatok alapján. Ezzel az elméleti háttérrel a két tudományterület egymásra találása törvényszerü volt miután a fordítástudományban bekövetkezett paradigmaváltásnak köszönhetően a fordítás eredményeképpen keletkezett szöveget már nem másodrangú, hanem egyenértékü szövegnek tekintették. Az alábbiakban a brit nyelvészeti tradíció néhány meghatározó elvét ismertetem és mutatom be, hogyan járult hozzá a korpuszalapú fordításkutatás kialakulásához, majd a mellett érvelek, hogy a korpusznyelvészetben kidolgozott analitikus eszközöket alkalmazni lehet a fordított szöveg nyelvi mintázatainak vizsgálatára.

Kulcsszavak: brit nyelvészeti tradíció, fordítási univerzálék, kollokáció, korpusz, nyelvi mintázatok

\section{Bevezetés}

Huszonöt év telt el, amióta megjelent az első tanulmány, amely felvázolta a korpuszalapú fordításkutatásban rejlő lehetőségeket, mégpedig Mona Baker (1993) tollából. A cikk két önálló kutatási terület, a korpusznyelvészet és a fordítástudomány lehetséges kapcsolódási pontjait körvonalazta. Nem mellesleg e sorok írásának időpontjában az említett tanulmány több mint 1.700 független hivatkozással rendelkezik; tudománytörténeti jelentőségén túl

Balaskó Mária: Korpuszalapú fordítástudomány, és ami mögötte van. In: Robin E., Seidl-Péch O. (szerk.) 2020. Fókuszban a forditott és a tolmácsolt szöveg: korpuszalapú forditáskutatás Magyarországon. Segédkönyvek a nyelvi közvetítésröl I. Budapest: ELTE BTK Fordítástudományi Doktori Program, MANYE Fordítástudományi Szakosztály. DOI: https://doi.org/10.36252/Nyelvikozvsegedkonyv1.3 
annak is köszönheti ismertségét, hogy a 20. század második felének egyik legjelentősebb, iskolateremtő nyelvésze, John Sinclair tiszteletére szerkesztett ünnepi könyvben jelent meg (Baker, Francis és Tognini-Bonelli 1993). Mona Baker John Sinclair-tanítvány volt egy olyan időszakban, amikor a lehető legkedvezőbb együttállás segítette a korpuszalapú fordításkutatás megszületését: a számítógépes technológia elegendően fejlett és felhasználóbaráttá vált, a Sinclair-iskolában jelentős tapasztalat és tudás halmozódott fel a számítógépes korpuszok feldolgozásáról, és szintet lépett a fordítástudomány, amikor a leíró fordítástudomány (Toury 1995) felé fordult.

A korpusznyelvészet és a leíró fordítástudomány egymásra találása törvényszerü volt, ugyanis mindkét tudományterület arra a szemléletmódra támaszkodik, hogy a nyelvet úgy kell leírni, ahogyan az a nyelvhasználatban létezik, mégpedig valódi, nem mesterségesen előállított, kitalált nyelvi adatok alapján. Ennek a személetnek az elfogadásához a fordítástudományban szükség volt arra a paradigmaváltásra, amelynek köszönhetően a fordítás eredményeképpen keletkezett szövegre már nem másodrangú, hanem egyenértékü szövegként tekintettek.

A korpusznyelvészet fejlődését eleinte nemcsak a technológia kezdetlegessége akadályozta, hanem a nyelvtudomány fősodrát a 20. század második felében uraló racionalista megközelítésmód is. Ezzel egy időben, ennek a szemléletmódnak az ellenpólusán müködött egy szellemi mühely, amelynek alapjait az 1930-as években J. R. Firth fektette le (1935, 1957a, 1957b) a korábbi brit nyelvészeti hagyományokat követve, majd tanítványainak egymást követő generációi, M.A.K. Halliday és John Sinclair fejlesztettek tovább.

Az úgynevezett brit tradíció egyik alaptétele, hogy a nyelvészetet társadalomtudománynak és alkalmazott tudománynak tekinti, ami teljesen szemben áll a racionalista felfogással. A másik fontos ismérv az előzőből következik: amennyiben a nyelv társadalmi jelenség, azt természetes módon keletkezett, létező szövegekből kiindulva kell vizsgálni. Megkülönböztetett figyelmet kap a jelentés, ami idővel arra a felismerésre vezette a neo-firthiánusokat, hogy nyelvi megformálás és jelentés elválaszthatatlanok egymástól, és hogy nyelvtan és szókészlet szorosan összefüggenek egymással. Ezek a gondolatok hatá- 
rozták meg John Sinclair teljes munkásságát, benne a Sinclair által képviselt korpusznyelvészeti irányzatot, és hatottak közvetve Mona Baker fordításról való gondolkodására is.

Noha Mona Baker a fordítási univerzálék $(1993$; 1996) meghatározásával alapozta meg a korpuszalapú fordításkutatást, ezek egy tágabb konceptuális keretben helyezkednek el, amelynek értelmében a fordítás eredményeként létrejött szöveg természetében más, mint az eredetileg adott célnyelven alkotott szövegek. A fordítás a nyelvhasználat egyedi változata, ugyanis a szövegprodukció minden egyéb fajtájától eltérően korlátozóan hat rá egy másik nyelven megfogalmazott szöveg (Baker 2005). Azaz a fordítás eredményeképpen létrejött szöveg egy olyan folyamat produktuma, amelynek során a fordító más gondolatait más szavaival más nyelven fogalmazza újra. Ebből természetesen következik, hogy a fordítás saját jellegzetes nyelvi mintázatokba rendeződik.

\section{A nyelvi mintázatokról}

A nyelvszerkezetet a szókészlettől független rendszernek tekintő felfogás a múlté. Számos önálló tudományterületen végzett kutatás jutott egymástól függetlenül ugyanarra az eredményre, hogy az élö nyelv morfémák többé-kevésbé rögzített sorozatából áll. Ezeket a sorozatokat elméleti háttértől függően nevezik lexikális kifejezéseknek (lexical phrases) (Nattinger és DeCarrico 1989; 1992), kompozitáknak (composites) (Mitchell idézi Cowie 1988), nyitólépéseknek (gambits) (Keller idézi Cowie 1988), rutinszerü képleteknek (routine formulae) (Coulmas idézi Cowie 1988), frazémáknak (phrasemes) (Melčuk 1988; 1995), előre gyártott rutinoknak és mintázatoknak (prefabricated routines and patterns) (Krashen 1981), és még sorolhatnánk. Más szóval, az élő nyelv előre gyártott elemekből, panelekböl építkezik. Ebben a kontextusban nyer értelmet Sinclair (1991a) frazeológiai elve (idiom principle), amely korpusznyelvész és lexikográfusi tapasztalata szerint mélyen áthatja az írott és a beszélt nyelvet. Noha megállapításait a világviszonylatban is legtöbbet kutatott angol nyelv vonatkozásában fogalmazta meg, feltételezhetjük, hogy a többi nyelv esetében is ez a müködési elv érvényesül. 
A frazeológiai elv szerint a szöveg nem véletlenszerủen kiválasztott egymást követő szavakból keletkezik, hanem számos előre vagy félig előre gyártott szerkezetből áll össze, amelyek adott helyzetben az egyetlen választási lehetőséget jelentik akkor is, ha látszólag ezek a szerkezetek szétválaszthatók. A frazeológiai elv müködésének egyik klaszszikus példája a két szóból álló angol of course. Ez a szókapcsolat gyakorlatilag egyetlen szóként működik és a szóköz idővel ki fog kopni, mint ahogy az történt a maybe, anyway, another szavak esetében. Az of ebben a szerkezetben nem a nyelvtankönyvekben megtalálható of elöljáró, amely általában egy főnévi csoport főneve után következik, vagy egy mennyiségjelzőben, mint a pint of. Hasonlóképpen a course sem az a megszámlálható főnév, amely a szótárakban szerepel, jelentése pedig nem a szó tulajdonsága, hanem a szókapcsolaté (vö. Sinclair 1991a).

A frazeológiai elvvel szemben áll a szabad választás elve (open-choice principle) (Sinclair i.m.), amely a szöveget egy bonyolult kiválasztási folyamat eredményének tekinti, amit egyedül a nyelvtani helyesség korlátoz. Azaz minden szót, szókapcsolatot vagy mondatot bármilyen más szó, szókapcsolat, mondat követhet, ha az megfelel a nyelvtani helyesség szabályainak. Könnyen belátható, hogy ha a nyelvben csupán a szabad választás elve müködne, nem tudnánk elfogadható szöveget alkotni.

A korpusznyelvészeti kutatások (Sinclair (1991a), Kjellmer (1994), Altenberg és Olofsson (1990) és Moon (1998)) kiterjesztették a frazeológia határait, hogy az magába foglalja a klasszikus, ámde nyelvhasználati gyakoriságukat tekintve meglehetősen ritka, átvitt értelmủ kötött frazeológiai egységeken kívül, a szavak számos olyan laza kombinációját, amelyekben gyakori az együttes előfordulás. Mivel ezek a többszavas kifejezések gyakran ismétlődnek és szokványosak, a hétköznapi nyelvhasználatban észre sem vesszük, hogy előre gyártott elemeket használunk. Mindezek ellenére a több szóból álló egységek képezik az írott és a beszélt nyelv tipikus és előnyben részesített építőelemeit. A több szóból álló egységek együttes kiválasztás (koszelekció) eredményeként jönnek létre. A koszelekció azt jelenti, hogy a nyelvhasználat két vagy több elemet rendszeresen, szokásszerűen „csomagként” választ ki. A szavak koszelekciós hajlama kiemelkedően erős. 
A több szóból álló elöre gyártott elemek építőkövei a kollokáció és a kolligáció. A fogalmak, melyek közül az előbbi széles körben ismert, Firthtől származnak, aki egy népszerü közmondást módosítva írja körül a jelenségeket: „You shall know a word by the company it keeps [...]" (Firth 1957b: 11), azaz madarat tolláról, szót barátjáról. Fontos hangsúlyozni, hogy a szóban forgó szintagmatikus viszonyok konkrét szavak között, és nem kategóriák között keletkeznek. A kollokáció két vagy több szó ismétlődő együttes előfordulása, míg a kolligáció az a grammatikai mintázat, amelybe egy állandósult szókapcsolat illeszkedik. Másképpen: bizonyos szavak és szóalakok vagy vonzzák, vagy kerülik egymás társaságát. A kollokációkat és a kolligációkat korpuszokból készített konkordanciák hozzák felszínre, amelyek függőleges oszlopaiban kirajzolódnak az ismétlődő mintázatok vagy panelek.

A Sinclair vezetésével megvalósult két korszakalkotó korpuszalapú munka, a Collins Cobuild English Dictionary (Sinclair 1987) és a Collins Cobuild English Grammar (Sinclair 1990) tanulságait Stubbs (1993) összegzi. Az alábbiakat tartom közülük ezen a helyen fontosnak kiemelni:

1. Minden nyelvtani szerkezet megszabja, milyen szókészleti elemeket lehet benne felhasználni, és viszont: minden szókészleti elem meghatározható azoknak a nyelvtani szerkezeteknek az alapján, amelyekben előfordul.

2. A ragozási paradigmában nem állandó, azaz változik a lemma jelentése.

3. Egy szó minden külön jelentésének megvan a saját grammatikája; mindegyik jelentéshez egyedi, jellegzetes nyelvi mintázat kapcsolódik. Nyelvi megformálás és jelentés nem választhatók el egymástól.

4. A nyelv szokásszerü használatát a koszelekció, vagyis az együttes kiválasztás irányítja.

A fentiek szemléltetésére álljon itt néhány példa. 
Az első pont érvényességét támasztja alá az információs szerkezetről szóló fejezet fókuszt tárgyaló részénél a Collins Cobuild English Grammar leírásában (Sinclair 1990: 410) található alábbi kolligációs mintázat:

$$
\text { all / what + PRONOUN + VERB + BE + NOUN }
$$

Mint például All you need is love. A 7,2 millió szövegszóból álló korpusz alapján végzett elemzés kimutatta, hogy a szerkezetben előforduló igék száma egynéhányra korlátozódik, mi több, azok szemantikailag egymáshoz kapcsolódnak: adore, dislike, enjoy, hate, like, loathe, love, need, prefer, want. Más igék nem fordulnak elö ebben a mintázatban.

Egy másik megállapítást igazol a set in többszavas ige elemzése. Egyik alakja, a set, sokkal többször fordul elö, mint a ragozott sets vagy a toldalékolt setting alak. Konkordanciavizsgálatok kimutatták, hogy az ige leggyakoribb használata múlt idejü, általában (tag)mondat vége felé helyezkedik el, és alanyai döntően elvont fönevek, mégpedig a kellemetlen fajtából: rot, disillution (Sinclair 1991a).

Ellenörzésképpen lekérdeztem a többszavas ige konkordanciáját a MicroConcord (Scott és Johns 1993) kb. 2 millió szövegszóból álló korpuszából. Az önálló set ige összesen 41-szer fordult elö, és ebből 32 esetben követte az in prepozíció. Terjedelmi okokból alább csak a többszavas igét tartalmazó maradék konkordanciasorokat közlöm:

Ez a néhány példa is szemléletesen mutatja, hogyan rendeződik a kulcsszó (set in) a Sinclair által leírt mintázatba. Az alanyok (ahol láthatóak) különösen figyelemre méltóak: deterioration, unmitigated disaster, error and madness, deterioration in mood, complications, foot-rot, loss/decline in confidence.

Az a tény, miszerint egy kisméretü korpuszban az összes előfordulás a nagyságrendekkel nagyobb korpusz eredményeit tükrözi, megerősíti, hogy a leírt nyelvhasználati mintázat tipikus. 
1. ábra

\begin{abstract}
A set in konkordanciája a MicroConcord korpuszban (Scott és Johns 1993)
we expected. Clearly some deterioration has set in." <p> He said that Sky

to unmitigated disaster only seems to have set in from 1942 onwards. <p> F as involvement of the fallopian tubes, have set in. Rectal discharge may oc on remained passive until error and madness set in near the end; then she ntinental ally) and a deterioration in mood set in owing to the threatening our. These complications are only likely to set in if the infection has bee eal with the foot-rot which was starting to set in. Another problem was the imself. $\quad\langle\mathrm{p}>$ The loss of confidence which set in after Stalingrad was not the inevitable decline in confidence which set in during the following wee
\end{abstract}

Az utolsó példa egy hétköznapi főnév egyes és többes számú alakjainak eltérő viselkedését mutatja be. Az eye, illetve az eyes alak teljesen különböző mintázatokban jelenik meg. A többes számú alak például a blue, brown, covetous, manic melléknevekkel együtt fordul elö, míg az egyes számú alak szinte soha nem utal a látószervre. Ugyanakkor a főnév tipikus használatára egyes és többes számban egyaránt az idiomatikus szerkezet és az átvitt értelmü jelentés jellemzö: all eyes will be on, rolling their eyes, turn a blind eye, keep an eye on (Sinclair 1991b).

A fenti példák látszólag annyira triviálisak, hogy könnyü alábecsülni a megállapítások jelentőségét. Hétköznapiságuk ellenére - vagy épp miatta - ezeket és a hozzájuk hasonló nyelvi jelenségeket korpuszok és belőlük készített konkordanciák nélkül nem lehetett volna azonosítani. Az élő nyelv természetének és viselkedésének megismerésére az intuíció nem annyira alkalmas - még a nyelvészé sem -, mint azt feltételezték; több engedményt tesz a lehetséges számára és elsiklik a tipikus felett. Ha valaki kérte már ki nem anyanyelvüként anyanyelvi beszélő véleményét, annak ismerősnek hangozhat az egyenválasz: ,igen, helyes; de várjunk csak, most, hogy alaposan belegondolok, nem szokták így mondani." 
A korpusznyelvészeti vizsgálatok a nyelvi valóság semmilyen más eszközzel nem megfigyelhető részletgazdagságát tárják fel, és korábbi ismereteinkhez képest eredményei egy teljesen újszerü, esetenként meglepő képet alakítanak ki nyelvről és nyelvhasználatról. A Firth által elméleti alapokra helyezett, majd kutatási eredményeik alapján követői által továbbfejlesztett brit nyelvészeti tradíció elsőként egy lexikográfiai munkában teljesedett ki. Ez volt a John Sinclair föszerkesztésében kiadott, 2018-ban 9-ik kiadásánál tartó Collins Cobuild English Dictionary (1987), amely forradalmasította a szótártudományt, és követendő mintául szolgált minden jelentős, elsősorban nyelvtanulói szótárakban érdekelt brit könyvkiadó számára - a Longmantől az Oxfordig - a rákövetkező években megjelenő megújult kiadásaik elkészítéséhez. A szótárkészítés tapasztalata alapján, és ugyanannak a közben folyamatosan bővülő korpusznak a felhasználásával jelent meg szintén John Sinclair irányítása alatt a Collins Cobuild English Grammar (1990) funkcionális grammatika, amelyben a szó jelentése kiemelt szerephez jut. A grammatika segédszerkesztői között megtaláljuk Mona Baker nevét is. Ennek a két főmunkának „melléktermékeként” jelent meg tíz további segédkönyv Collins Cobuild English Guides 1-10 gyüjtöcím alatt, amelyek elsősorban nyelvtanulóknak nyújtanak segítséget többek között a névelök, kötőszók, elöljárószók használatához. A Cobuild-mühely korpusznyelvészeti módszere és az ott képviselt nyelvészeti szemlélet átterjedt egyéb nyelvtudományi és alkalmazott nyelvészeti területekre, amelyeket ma már lehetetlen mind számba venni. A teljesség igénye nélkül: frazeológia (Moon 1998), szókészlet (Hoey 2005), lexikális szemantika (Stubbs 2001), diskurzuselemzés (Tognini-Bonelli és Del Lungo Camiciotti 2005), idegennyelv oktatás (Tognini-Bonelli 2001), fordítástudomány (Olohan 2004). A mintázatok vizsgálata egyre nagyobb érdeklődést vált ki, és elsősorban - ismét csak néhány témát kiemelve - a lexikai elemek grammatikai mintázatainak (Hunston és Francis 2000) vagy a szövegszerveződés mintázatainak a leírására (Hoey 1991), a nyelv és kultúra összefüggéseinek vizsgálatára (Stubbs 1996) és a kontextusnak a lexikai egység megértésében játszott szerepére (Hanks 2013) fókuszál. 


\section{Korpuszok a fordításkutatásban}

Függetlenül attól, hogy egy- vagy többnyelvűek, a fordítás kutatására összeállított korpuszok elsődleges tulajdonsága, hogy két komponensből vagy modulból állnak. Ez természetes, hiszen minden elemzésnek, de még a leírásnak is az összehasonlítás a módszertani alapja: célnyelvi szöveget hasonlítunk össze forrásnyelvi szöveggel, célnyelvi szöveget azonos célnyelven keletkezett elsődleges szöveggel, egy adott célnyelvü szöveget egy másik célnyelvű szöveggel, eltérő forrásnyelvekből származó célnyelvi szövegeket egymással és így tovább.

Más fiatal (rész)diszciplínákhoz hasonlóan a korpuszalapú fordítástudományban is vannak megoldásra váró terminológiai kérdések. Leginkább a korpusz-típusok elnevezése okoz következetlenségeivel nem kevés zavart. Különböző szerzőknél, kutatóknál más elnevezés alatt találjuk meg ugyanazt a korpusz típust, illetve azonos elnevezéssel más típusú korpuszra utalnak (Seidl-Péch 2018:183-184). Ezért mindig fontos tisztázni, melyik szerző pontosan mit ért az általa használt fogalmon.

Az alábbiakban három fordításhoz kapcsolódó korpuszról lesz szó: a párhuzamos, a fordítási és az összehasonlítható korpuszról. A párhuzamos korpusz azonos kritériumok szerint válogatott két vagy több forrásnyelvü szövegeket tartalmaz; a korpuszban szereplő szövegek nem fordításai egymásnak, hanem hasonló tartalmú forrásnyelvi szövegek, mint például a Council of Europe Multilingual Lexicography Project vagy The Aarhus Corpus of Contract Law. Látszólag nincs sok közük a fordításhoz, mégis értékes adatforrások azáltal, hogy eredeti célnyelvi mintákat mutatnak a fordítók, a fordító képzésben részt vevők és a fordításkutatók számára egyaránt.

A fordítási korpusz forrásnyelvi szövegeket és azok célnyelvi megfelelőit tartalmazza. Nem meglepő módon ez a leggyakoribb korpusz a fordítói gyakorlatban, különösen, ha figyelembe vesszük, hogy minden fordítómemória gyakorlatilag folyamatosan új szövegpárokkal bővülő fordítási korpusz, de a kezdeteknél ott találjuk a kanadai franciaangol Hansard Corpust. Gyakorló fordítóknak, leendő fordítóknak segítenek gyorsabban megtalálni a célnyelvi megoldásokat vagy profi fordítók mintaként használható megoldásait, fordításkutatóknak pedig lehetővé teszik a fordítási normák vizsgálatát. 
Az összehasonlítható korpusz eredetileg célnyelven keletkezett, valamint azonos célnyelvü, de fordítás eredményeképp keletkezett szövegeket tartalmaz. Ideális esetben az egyetlen változó a korpuszban a szöveg keletkezésének körülménye, azaz hogy fordítás vagy nem fordítás. Ezen túl minden egyéb paraméter mindkét korpuszkomponensben azonos (szövegfajta, téma, hossz, keletkezés ideje és így tovább). Az összehasonlítható korpuszok betekintést nyújtanak a fordítás eredményeképpen létrejött szöveg természetébe, illetve biztosítják a terepet a fordítási univerzálék kutatásához. Ezen oknál fogva elsősorban a fordításkutatás számára fontosak ezek a korpuszok, ugyanakkor a vizsgálati eredmények a fordításoktatásban is felhasználhatók az eredeti és a fordítás eredményeképpen létrejött célnyelvi szövegek közötti különbségek tudatosítására.

Az ideális korpusz minden fordításkutató számára a kétirányú (bidirekcionális) korpusz. Az English Norwegian Parallel Corpus (Johansson 1998) mintájára több skandináv ország elkészítette saját kétirányú korpuszát (vö. Aijmer et al. 1996, Aijmer és Altenberg 2000, Mauranen 2000), amely magában foglalja az elözőekben bemutatott korpuszfajtákat. A korpuszmodulok összepárosításától függően a korpuszt lehet fordítási korpuszként két irányban, összehasonlítható korpuszként, párhuzamos korpuszként, és fordított szövegek párhuzamos korpuszaként használni. Könnyen belátható, milyen széles körủ egy ilyen korpusz felhasználhatósága, és mennyi lehetőséget rejt magában fordító és kutató számára egyaránt. Egy bidirekcionális korpusz létrehozásához azonban szerzői jogi kérdéseken túl egyéb akadályokat is le kell küzdeni. Az összehasonlíthatóság érdekében az egyes modulok méretének és tartalmának meg kell egyeznie, ami nyelvpároktól függően könnyebben vagy nehezebben valósítható meg. Hogy mit és mennyit fordítanak egy adott korban és egy adott kultúrában függ a forrásnyelv és a forrásnyelvi kultúra célnyelvi kultúrában elfoglalt helyétől, státuszától. Nyilvánvaló aránytalanságok vannak „,nagy” és „kis” nyelvek között, ugyanis lényegesen kevesebb fordítás áramlik „nagy” nyelvek felé, mint fordítva, ami korlátozza a merítést. Mégis, amit kutatóként, fordítóként nyerünk messze felülírja a korpuszkészítés nehézségeit, ezért minél több nyelvpár viszonylatában ajánlatos kétirányú korpuszokat létrehozni. 
2. ábra

Az ENPC szerkezete (Johansson 1998: 8)

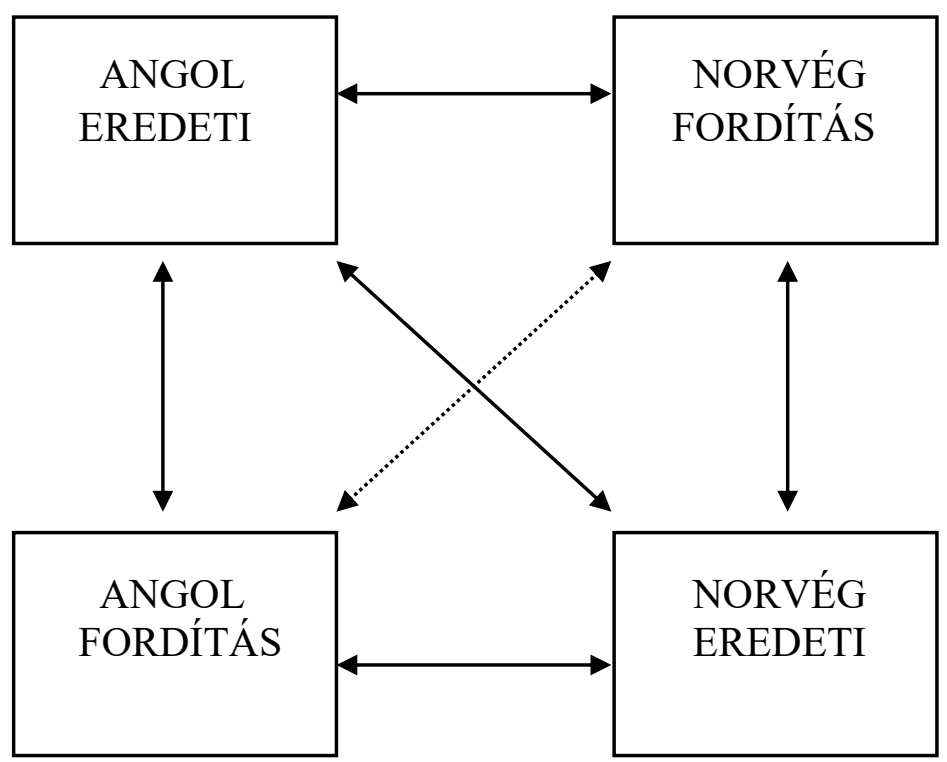

\section{Amit korpuszokból lehet megtudni a fordításról}

A korpuszok megjelenésével kutathatóvá vált számos téma közül a fordítási univerzálékra irányult a legnagyobb figyelem (vö. Hansen 2000, Jantunen 2000, Laviosa-Braithwaite 1996, Laviosa 1997; 1998, Pápai 2001; 2002, Tirkkonen-Condit 2000, Zanettin 2000). Már korábban is felmerült, hogy a fordítás eredményeképpen keletkezett szövegeknek olyan jegyeik vannak, amelyek semmilyen egyéb körülmények között keletkezett szövegekre nem jellemzök (vö. Blum-Kulka 1986, Toury 1995). Ahhoz azonban, hogy a kutatások szintet léphessenek, fordítás eredményeképpen keletkezett szövegek nagy mennyiségére volt szükség, továbbá korpusznyelvészeti módszerekre és eszközökre az adatok vizsgálatához (vö. Kohn 1996). A fordított szövegek jellegzetességeinek korpuszok segítségével történő vizsgálatát Baker $(1993 ; 1996)$ vetette fel elsőként. A fordított szövegekben nyel- 
vpároktól, fordítási iránytól, szövegtípustól, a fordítási folyamat egyéb körülményeitöl függetlenül megjelenő jegyeket fordítási univerzáléknak nevezi. A tudományos diskurzusban részt vevő kutatók egy része tényként fogadja el a fordítási univerzálék létezését, és különböző hipotéziseket tesztelnek (például Laviosa 2002, Olohan 2004, Zanettin 2012), kutatásmódszertani kérdéseket vetnek fel (Bernardini és Zanettin 2004, Zanettin 2012), konceptuális kérdéseket tisztáznak (Chesterman 2004), vagy kognitív nyelvészeti alapon magyarázzák müködésüket (Halverson (2003; 2010). Ugyanakkor kritikus hangok is megjelentek, amelyek például a fogalom tartalmi homályosságára mutatnak rá (Malmkjaer 2008), létezésüket megkérdőjelezik (vö. Tymoczko 1998), vagy határozottan visszautasítják (House 2008, Becher 2010).

Annak ellenére, hogy sok kérdőjel merül fel a fordítási univerzálék körül, és vita tárgyát képezi az is, hogy pontosan mi minősül univerzálénak (vö. Tirkkonen-Condit 2002; 2004), a kutatások többsége számára Baker (1996) osztályozása jelenti a kiindulópontot, az univerzálék négy csoportját különítve el: az explicitáció, a szimplifikáció, a normalizáció (más néven konzervativizmus vagy standardizáció) és a kiegyensúlyozás (levelling out).

Tekintettel arra, hogy a tanulmánygyüjtemény egyik írása részletesen foglalkozik a fordítási univerzálékkal, a következőkben csak néhány észrevétel erejéig térek ki a témára. Csakúgy, mint az univerzálék kérdésénél általában, az egyes fordításiuniverzálé-jelöltek körül sem kevés az ellentmondás, homályosság és átfedés. Az explicitációval, például, jelentős számú kutatás foglalkozik a korpuszok megjelenése előtt és után (vö. Baker 1995; 1996, Olohan és Baker 2000, Blum-Kulka 1986, Heltai 2003, Klaudy 1993; 1996; 1998; 1999, Laviosa-Braithwaite 1996, Laviosa 1998, Pápai 2001; 2002, Séguinot 1988, Weissbrod 1992), elkészült több tipológia (Klaudy 1999; 2008, Englund Dimitrova 2005, Robin 2015; 2018), a fogalom meghatározása mégis ingadozik jelenség, tendencia vagy müvelet között, és máig is folyik annak tisztázása, mi tekinthető explicitációnak (vö. Balaskó 2004), de az sem egyértelmü, hogy fordítási univerzálénak számít-e egyáltalán az explicitáció (Becher 2010). Ugyanezek a kérdések merülnek fel a szimplifikáció és a normalizáció, vagy más néven standardizáció kapcsán. A fordított szöveg nyelvezetének és/ 
vagy üzenetének egyszerüsítésére irányuló vizsgálatok eredményei például nem koherensek: egy részük igazolja (Laviosa-Braithwaite 1996, Laviosa 1997; 1998), más részük cáfolja a szimplifikáció jelenlétét a fordított szövegekben (Mauranen 2000, Jantunen 2001). Hasonlóan vitatható eredmények születtek a normalizációvizsgálatokban (vö. Kenny 2000, Mauranen 2008, Teich 2001, Hansen 2003), amelyek azt próbálták megállapítani, hogy a fordítások valóban a célnyelv tipikus nyelvhasználati mintáihoz igazodnak, illetve hogy a fordítók valóban kihangsúlyozzák-e a célnyelv jegyeit. A legkevesebb kérdőjel a kiegyensúlyozás körül merül fel, de ez elképzelhetően annak köszönhető, hogy mindezidáig erre az univerzáléjelöltre irányult a legkevesebb figyelem. A vizsgálatok azt a hipotézist próbálják alátámasztani, hogy a fordított szövegek semlegesebbek, homogénebbek, kevésbé egyediek, mint az eredeti szövegek, ezért egy fordítási korpusz egyes szövegei között kisebb a variáció, mint egy eredeti szövegekből álló korpusz szövegei között.

Az univerzálékutatás továbbra is izgalmas területe a fordítástudománynak, hiszen magában hordozza a törvényszerüségek felfedezésének ígéretét. Még ha nem is azokra a kérdésekre kaptunk válaszokat, amelyeket feltettünk, a kapott válaszok rendkívüli mértékben gazdagítják tudásunkat a fordított szöveg természetéről. Az időszakos elakadások ellenére folytatni kell a kutatásokat, de közben ismétlődően fel kell tenni a kérdést, hogy megfelelő módon és megfelelő célra használjuk-e a korpuszokat.

\section{Nyelvi mintázatok a fordításban}

Míg a Sinclair által képviselt korpusznyelvészeti irányzat hagyományosan az alulról felfelé módszert alkalmazva jut el a nyelvi adattól az általánosításig, az alapjain kialakult korpuszalapú fordításkutatás áttért a felülröl lefelé módszerre, hogy bizonyítékokkal támaszsza alá a fordítási univerzálékhoz kapcsolódó hipotéziseket, mint láttuk több-kevesebb sikerrel. Ha nem is kell teljesen elvetni ezt a fajta megközelítést, feltétlenül szükségesnek tartjuk kiegészíteni az alulról felfelé módszert alkalmazó vizsgálatokkal, amelyek nyelvi tényekből kiindulva segíthetnek azonosítani azokat a jegyeket, amelyek megkülönbözte- 
tik a fordítás eredményeképp keletkezett célnyelvi szövegeket az eredetileg célnyelven keletkezett szövegektől.

Mint ahogyan arra korábban rámutattunk, a nyelv nagyrészt panelekből épül fel, és jellegzetes mintázatokba rendeződik. Ha a nyelvi transzfertevékenység nem hagyna nyomott a fordított szövegen, az azonos paraméterekkel (például azonos müfaj, téma, keletkezési idö) rendelkező szövegeknek azonos panelekből kellene építkezniük, függetlenül attól, hogy fordítások vagy nem-fordítások. Az összehasonlítható korpuszokkal végzett kutatások azonban azt mutatják, hogy keletkezésük sajátos körülményei miatt a fordított szövegek a szokásostól eltérő mintázatokba rendeződnek.

Egy igei kulcsszó konkordanciavizsgálatánál például eltérő mintázatok rajzolódtak ki a paradigmatikus és a szintagmatikus tengelyen egyaránt. Az ige paradigmájának másmás alakjai fordultak elő fordított és nem-fordított szövegekben, és rendeződtek egymástól teljesen különböző mintázatokba. A fordított szövegektől eltérően az eredeti célnyelvi szövegekben kevesebb és lazább mintázatok körvonalazódtak (Balaskó 2012). Hasonló eredményre jutott Baroni és Bernardini (2003), akik sokkal erősebb, stabilabb kollokációs kapcsolatokat találtak fordított szövegekben, mint nem-fordított szövegekben, ahol a kollokációs kapcsolatok nagyon gyengék voltak. Egyéb kollokáció-vizsgálatokból az derült ki, hogy fordított szövegekben gyakran fordulnak elő olyan szókapcsolatok, amelyek léteznek és elfogadottak ugyan a célnyelvben, eredeti célnyelvi szövegekben mégsem, vagy csak ritkán fordulnak elő (Mauranen 2008), Jantunen (2001) pedig teljesen eltérő kollokációs mintázatokat talált fordított, illetve nem-fordított szövegekben. A nyelvi mintázatokról szóló részben bemutatott konkordancia-elemzés módszerét alkalmazva, ugyancsak különböző mintázatokra derült fény egy főnévi kulcsszó vizsgálatánál. Nemcsak a mintázatok voltak különbözőek, hanem a teljes paradigma más-más alakjai fordultak elő fordított és nem-fordított szövegekben (Balaskó 2008). A nyelvi mintázatok vizsgálata messze túlmutat a mikroelemzések korlátain, és felveti többek között a fordítás egységének kérdését. A nyelvi mintázatokra irányuló vizsgálatok azt mutatják, hogy az erős forrásnyelvi mintázatok ugyanolyan erős célnyelvi mintázatokká állnak össze, amelyek a lehetséges, ámbár nem megszokott keretei között helyezkednek el, ha azok nem sértik 
a célnyelvi használat normáit. A dominóhatásnak köszönhetően pedig az eltérő mintázatokba rendeződő fordított szöveg az eredeti célnyelvi szövegtől különböző szöveggé állnak össze, melyet a kohézió szintjén eltolódások jellemeznek (vö. Blum-Kulka 1986, Seidl-Péch 2013, Károly 2017).

\section{6. Összegzés}

Az 1980-as évek közepéig a korpusznyelvészet nem volt több néhány megszállott kutató kísérletezésénél a lehetetlennel, majd fejlödött fokozatosan önálló nyelvtudományi diszciplínává és egyúttal vizsgálati módszerré. A John Sinclair nevéhez füződő korpusznyelvészeti irányzat módszerére alapozva vált a korpuszalapú fordításkutatás a fordítástudomány egyik marginális témájából új paradigmává, amely rövid időn belül bekerült a leíró fordítástudomány fősodrába. A fordított szöveg természetének feltárására irányuló univerzálékutatást jelentős mennyiségü megfigyelési és kísérleti adat támogatja, ezek azonban olykor ellenbizonyítékokat is szolgáltatnak, megkérdőjelezve az univerzálék meghatározásának érvényességét és megfelelő kategóriákba való sorolását. Ezért az alkalmazott fentről lefelé módszert ki kell egészíteni a nyelvet alkotó panelek mintázatainak alulról felfelé történő, valamint a mintázatokba rendeződés teljes hatásmechanizmusának vizsgálatával.

\section{Irodalom}

Aijmer, K., Altenberg, B., Johansson, M. 1996. Text-based contrastive studies in English. Presentation of a project. In: Aijmer, K., Altenberg, B., Johansson, M. (eds) Languages in Contrast. Papers from a Symposium on Text-based Cross-linguistic studies. Lund 4-5 March 1994. Lund: Lund University Press. 73-85.

Aijmer, K., Altenberg, B. 2000. The English-Swedish Parallel Corpus: A resource for contrastive research and translation studies. In: Mair, Ch., Hundt, M. (eds) Corpus Linguistics and Linguistic Theory. Papers from the Twentieth International Conference on English Language Research on Computerized Corpora. (ICAME 20) Freiburg im Breisgau 1999. Amsterdam-Atlanta GA: Rodopi. 15-33. 
Altenberg, B., Olofsson, M. E. 1990. Phraseology in spoken and written English: Presentation of a project. In: Aarts, J., Meijs, W. (eds) Theory and practice in corpus linguistics. Amsterdam-Atlanta GA: Rodopi. 1-26.

Baker, M. 1993. Corpus Linguistics and Translation Studies. Implications and Applications. In: Baker, M., Francis, G., Tognin-Bonelli, E. (eds) Text and Technology: In Honour of John Sinclair. Amsterdam: John Benjamins. 233-250. https://doi.org/10.1075/z.64.15bak

Baker, M., Francis, G., Tognin-Bonelli, E. (eds) 1993. Text and Technology: In Honour of John Sinclair. Amsterdam: John Benjamins. https://doi.org/10.1075/z.64

Baker, M. 1995. Corpora in Translation Studies. An Overview and Suggestions for the Future Research. Target Vol. 7. No. 2. 223-245. https://doi.org/10.1075/target.7.2.03bak

Baker, M. 1996. Corpus-based translation studies: The challenges that lie ahead. In: Somers, H. (ed) Terminology, LSP and Translation. Studies in language engineering in honour of Juan C. Sager. Amsterdam/Philadelphia: John Benjamins. 175186. https://doi.org/10.1075/btl.18.17bak

Baker, M. 2005. Linguistic models and methods in the study of translation. In: Kittel, H., Frank, A. P., Greiner, N., Hermans, T., Koller, W., Lambert, J., Paul, F. (eds) Übersetzung. Translation. Traduction. Berlin, New York: Walter de Gruyter. 285294.

Balaskó M. 2004. Korpusznyelvészeti vizsgálatok és fordításnyelvi minták. Doktori diszszertáció. Pécsi Tudományegyetem.

Balaskó, M. 2008. What Does the Figure Show? Patterns of Translationese in a Hungarian Comparable Corpus. trans-kom Vol. 1. No. 1. 58-73.

Balaskó, M. (2012) „Elective affinities” - or Do words keep different company i translation? In: Karabalić, V., Aleksa Varga, M., Pon, L. (eds) Discourse and Dialogue. Frankfurt am Main: Peter Lang. 155-168. 
Baroni, M., Bernardini, S. 2003. A preliminary analysis of collocational differences in monolingual comparable corpora. In: Archer, D., Rayson, P., Wilson, A., McEnery, T. (eds) Proceedings of the Corpus Linguistics 2003 Conference. Technical Paper number 16, Special issue. Lancaster: UCREL, Lancaster University. 82-91.

Becher, V. 2010. Abandoning the notion of 'translation-inherent' explicitation: against a dogma of translation studies. Across Languages and Cultures. Vol. 11. No. 1. 1-28. https://doi.org/10.1556/Acr.11.2010.1.1

Bernardini, S., Zanettin, F. 2004. When is a universal not a universal? Some limits of current corpus-based methodologie for the investigation of tranlation universals. In: Mauranen, A., Kujamäki, P. (eds) Translation Universals - Do they exist? Amsterdam/Philadelphia: John Benjamins. 51-62. https://doi.org/10.1075/btl.48.05ber

Blum-Kulka, S. 1986. Shifts of Cohesion and Coherence in Translation. In: Blum-Kulka, S., House, J. (eds) Interlingual and Intercultural Communication: Discourse and Cognition in Translation and Second Language Acquisition Studies. Tübingen: Narr. 17-35.

Chesterman, A. 2004. Beyond the particular. In: Mauranen, A., Kuyamaki, P. (eds) Translation universals: Do they exist? Amsterdam/Philadelphia: John Benjamins. 3349. https://doi.org/10.1075/btl.48.04che

Cowie, A. P. 1988. Stable and creative aspects of vocabulary use. In: Carter, R., McCarthy, M. (eds): Vocabulary and Language Teaching. London: Longman. 126-139.

Dimitrova, E. B. 2005. Expertise and Explicitation in the Translation process. Amsterdam: Benjamins. https://doi.org/10.1075/btl.64

Firth, J. R. 1935. The Technique of Semantics. Transactions of the Philological Society. 36-72. https://doi.org/10.1111/j.1467-968X.1935.tb01254.x

Firth, J. R. 1957a A Synopsis of Linguistic Theory, 1930-1955. Studies in Linguistic Analysis. Special Volume of the Philological Society. 1-32. 
Firth, J. R. 1957b Papers in Linguistics. London: Oxford University Press.

Halverson, S. 2003. The cognitive basis of translation universals. Target Vol. 15. No. 2. 197-241. https://doi.org/10.1075/target.15.2.02hal

Halverson, S. 2010. Cognitive translation studies: developments in theory and method. In: Shreve, G. M., Angelone, E. (eds) Translation and Cognition. Amsterdam/Philadelphia: John Benjamins. 349-369. https://doi.org/10.1075/ata.xv.18hal

Hanks, P. 2013. Lexical analysis: norms and exploitations. Cambridge, Mass.: The MIT Press. https://doi.org/10.7551/mitpress/9780262018579.001.0001

Hansen, S. 2000. A Contrastive Analysis of Parallel and Comparable Corpora. Paper presented at the UMIST/UCL Research Models in Translation Studies Conference, Manchester, 28-30 April, 2000.

Hansen, S. 2003. The Nature of Translated Text: an Interdisciplinary Methodology for the Inspection of the Specific Properties of Translation. Saarbruecken Dissertations. Computational Linguistics and Language Technology. Vol. 13. Saarbruecken: University of Saarbruecken.

Heltai P. 2003. Az explicitáció egyes kérdései az angol-magyar szakfordításban. In: Feketéné Silye M. (szerk.) Porta Lingua: Szaknyelvoktatásunk az EU kapujában. Debrecen: DE ATC. 173-198.

Hoey, M. 1991. Patterns of Lexis in Text. Oxford: Oxford University Press.

Hoey, M. 2005. Lexical Priming. London/New York: Routledge.

House, J. 2008. Beyond Intervention: Universals in Translation? trans-kom Vol. 1. No. 1. 6-19.

Hunston, S., Francis, G. 2000. Pattern Grammar. A corpus-driven approach to the lexical grammar of English. Amsterdam/Philadelphia: John Benjamins. https://doi. org $/ 10.1075 / \mathrm{scl} .4$ 
Jantunen, J. 2000. What Can Corpora Tell us about Translated Language? A Comparable Corpus of Finnish in Use for Making Hypotheses. Paper presented at the UMIST/ UCL Research Models in Translation Studies Conference, Manchester, 28-30 April, 2000.

Jantunen, J. 2001. Synonymity and lexical simplifi cation in translations: A corpus-based approach. Across Languages and Cultures, Vol. 2. No. 1. 97-112.

Johansson, S. 1998. On the role of corpora in cross-linguistic research. In: Johansson, S., Oksefjell, S. (eds) Corpora and Cross-linguistic Research. Amsterdam-Atlanta GA: Rodopi. 3-24.

Károly, K. 2017. Aspects of coherence and cohesion in translation. Amsterdam/Philadelphia: John Benjamins. https://doi.org/10.1075/btl.134

Kenny, D. 2000. Translators at play: Exploitations of collocational norms in GermanEnglish translation. In: Dodd, B. (ed.) Working with German corpora. Birmingham: Uniersity of Birmingham Press. 143-160.

Kjellmer, G. 1994. A dictionary of English collocations. Oxford: Clarendon Press.

Klaudy, K. 1993. On explicitation hypothesis. In: Klaudy, K., Kohn, J. (eds) Transferre necesse est... Current issues of translation theory. Szombathely: BDTF. 69-77.

Klaudy, K. 1996. Back-Translation as a Tool for Detecting Explicitation Strategies in Translation. In: Klaudy, K., Lambert, J., Sohár, A. (eds) Translation Studies in Hungary. Budapest: Scholastica. 99-114.

Klaudy, K. 1998. Explicitation. In: Baker, M. (ed.) Routledge Encyclopedia of Translation Studies. London: Routledge. 80-84.

Klaudy K. (1999) Az explicitációs hipotézisről. Forditástudomány Vol. 1. No. 2. 5- 22.

Klaudy, K. (2008) Explicitation. In: Baker, M., Saldanha, G. (eds) Routledge Encyclopedia of Translation Studies. London: Routledge. 80-85. 
Kohn, J. 1996. What Can (Corpus) Linguistics Do for Translation? In: Klaudy, K., Lambert, J., Sohár, A. (eds) Translation Studies in Hungary. Budapest: Scholastica. $39-52$.

Krashen, S. D. 1981. Second Language Acquisition and Second Language Learning. Oxford: Pergamon Press.

Laviosa-Braithwaite, S. 1996. The English Comparable Corpus (ECC): A Resource and a Methodology for the Empirical Study of Translation. PhD Thesis. Manchester: Centre for Translation Studies, UMIST.

Laviosa, S. 1997. How Comparable Can 'Comparable Corpora' Be? Target Vol. 9. No. 2. 289-319. https://doi.org/10.1075/target.9.2.05lav

Laviosa, S. 1998. Core Patterns of Lexical Use in a Comparable Corpus of English Narrative Prose. Meta Vol 43. No. 4. 557-570. https://doi.org/10.7202/003425ar

Laviosa, S. 2002. Corpus-based Translation Studies: Theory, Findings, Applications. Amsterdam-Atlanta GA: Rodopi.

Mauranen, A. 2000. Strange strings in translated language: A study on corpora. In: Olohan, M. (ed), Intercultural faultlines: Research models in translation studies 1: Textual and cognitive aspects. Manchester: St. Jerome Publishing. 119-141.

Mauranen, A. 2008. Universal Tendencies of Translation. In: Anderman, G., Rogers, M. (eds) Incorporating Corpora: The Linguist and the Translator. Clevedon: Multilingual Matters. 32-48.

Malmkjaer, K. 2008. Norms and nature in translation studies. In: Anderman, G., Rogers, M. (eds) Incorporating Corpora. The Linguist and the Translator. Clevedon: Multilingual Matters. 49-59. https://doi.org/10.21832/9781853599873-007

Melčuk, I. 1988. Semantic description of lexical units in an Explanatory Combinatorial Dictionary: basic principles and heuristic criteria. International Journal of Lexicography. Vol. 1. No. 3. 165-188. 
Melčuk, I. 1995. Phrasemes in language and phraseology in linguistics. In: Everaert, M., van der Linden, E-J., Schenk, A., Schreuder, R. (eds) Idioms: structural and psychological perspectives. Hillsdale, N. J.: Lawrence Erlbaum Associates. 167-232.

Moon, R. 1998 Fixed expressions and idioms in English. Oxford: Clarendon Press.

Nattinger, J., DeCarrico, J. 1989. Lexical phrases, speech acts and teaching conversation. In: Nation, P., Carter, R. (eds): AILA Review 6: Vocabulary Acquisition. Amsterdam: AILA. 118-139.

Nattinger, J., DeCarrico, J. 1992. Lexical Phrases and Language Teaching. Oxford: OUP.

Olohan, M., Baker, M. 2000. Reporting that in Translated English. Evidence for Subconscious Processes of Explicitation? Across Languages and Cultures Vol. 3. No. 2. 141-158. https://doi.org/10.1556/Acr.1.2000.2.1

Olohan, M. 2004. Introducing Corpora in Translation Studies. London/New York: Routledge. https://doi.org/10.4324/9780203640005

Pápai V. 2001. Az explicitációs hipotézis vizsgálata. Doktori disszertáció. Pécsi Tudományegyetem.

Pápai V. 2002. Fordítási univerzálék: az explicitáció. In: Fóris Á., Kárpáti E., Szűcs T. (szerk.) A nyelv nevelö szerepe. A XI. Magyar Alkalmazott Nyelvészeti Kongreszszus elöadásainak válogatott gyüjteménye. Pécs: Lingua Franca Csoport. 486-493.

Robin E. 2015. Forditási univerzálék a lektorált forditásokban. Doktori értekezés. Budapest: ELTE.

Robin E. 2018. Forditási univerzálék és lektorálás. Budapest: Eötvös József Kiadó.

Scott, M., Johns, T. 1993. MicroConcord. Oxford: Oxford University Press.

Séguinot, C. 1988. Pragmatics and the Explicitation Hypothesis. TTR: Traduction, Terminologie, Rédaction Vol. 1. No. 2. 106-114. https://doi.org/10.7202/037024ar 
Seidl-Péch O. 2013. Célnyelvi szövegek nyelvtechnológiai eszközökkel támogatott lexikai kohéziós vizsgálata. In: Klaudy K. (szerk.) Forditás és tolmácsolás a harmadik évezred elején. ELTE Eötvös Kiadó. 95-106.

Seidl-Péch O. 2018. Melyek a (szak)fordító és a fordításkutató munkáját segítő legfontosabb nyelvi korpuszok? In: Robin, E., Zachar, V. (szerk.) Forditástudomány ma és holnap. Budapest: L'Harmattan Kiadó. 175-191.

Sinclair, J. 1987. Collins Cobuild English Dictionary. London: Collins.

Sinclair, J. 1990. Collins Cobuild English Grammar. London: Collins.

Sinclair, J. M. 1991a. Corpus Concordance Collocation. Oxford: Oxford University Press.

Sinclair, J. M. 1991b. Council of Europe Multilingual Lexicography Project. [Report submitted to the Council of Europe under contract no. 57/89.]

Stubbs, M. 1993. British Traditions in Text Analysis - from Firth to Sinclair. In: Baker, M., Francis, G., Tognin-Bonelli, E. (eds) Text and Technology: In Honour of John Sinclair. Amsterdam/Philadelphia: John Benjamins. 1-33. https://doi.or$\mathrm{g} / 10.1075 / \mathrm{z} .64 .02 \mathrm{stu}$

Stubbs, M. 1996. Text and Corpus Analysis. Oxford: Blackwell.

Stubbs, M. 2001. Words and Phrases: Corpus Studies of Lexical Semantics. Oxford: Blackwell.

Teich, E. 2001. Towards a model for the description of cross-linguistic divergence and commonality in translation. In: Steiner, E., Yallop, C. Exploring translation and multilinual text production: Beyond content. Berlin: Mouton de Gruyter. 191-227.

Tirkkonen-Condit, S. 2000. In Search of Translation Universals: Non-equivalence or 'Unique' Items in a Corpus Test. Paper presented at the UMIST/UCL Research Models in Translation Studies Conference, Manchester, 28-30 April, 2000. 
Tirkkonen-Condit, S. 2002. Translationese - a Myth or an Empirical Fact? Target Vol. 14. No. 2. 207-220. https://doi.org/10.1075/target.14.2.02tir

Tirkkonen-Condit, S. 2004. Unique items - over- or under-represented in translated language? In: Mauranen, A., Kujamäki, P. (eds) Translation Universals - Do they exist? Amsterdam/Philadelphia: John Benjamins. 177-184. https://doi.org/10.1075/ $\underline{b t 1.48 .14 t i r}$

Tognini-Bonelli, E. 2001. Corpus Linguistics at Work. Amsterdam/Philadelphia: John Benjamins. https://doi.org/10.1075/scl.6

Tognini-Bonelli, E., Del Lungo Camiciotti, G. (eds) 2005. Strategies in Academic Discourse. Amsterdam/Philadelphia: John Benjamins. https://doi.org/10.1075/scl.19

Toury, G. 1995. Descriptive Translation Studies and Beyond. Amsterdam/Philadelphia: John Benjamins. https://doi.org/10.1075/btl.4

Tymoczko, M. 1998 Computerized Corpora and the Future of Translation Studies. Meta Vol. 43. No. 4. 652-659. https://doi.org/10.7202/004515ar

Weissbrod, R. 1992. Explicitation in translations of prose-fiction from English to Hebrew as a function of norms. Multilingua Vol. 11. No. 2. 153-171. https://doi. org/10.1075/ata.v.22wei

Zanettin, F. 2000. Parallel Corpora in Translation Studies. Issues in Corpus Design and Analysis. In: Olohan, M. (ed.) Intercultural Faultlines. Research Models in Translation Studies I. Textual and Cognitive Aspects. Manchester, UK, Northampton MA.: St. Jerome. 105-118.

Zanettin, F. 2012. Translation-Driven Corpora. Corpus Resources for Descriptive and Applied Translation Studies. Manchester: St Jerome. https://doi.org/10.1016/j.sbspro.2013.10.618 